\title{
DNAJC25 as a tumor suppressor candidate gene in breast cancer
}

\section{Meme Kanserinde tümör baskılayıcı gen adayı olarak DNAJC25}

\section{Tolga Acun}

Department of Molecular Biology and Genetics, Faculty of Sciences and Arts, Zonguldak Bulent Ecevit University, Zonguldak, Turkey.

\section{ABSTRACT}

D NAJC25 gene is a member of the HSP40 (DNAJ) family, and it was suggested as a tumor suppressor gene in hepatocelIular carcinoma. The aim of this study was to analyze the expression, genetic/epigenetic alterations, and prognostic value of the DNAJC25 gene in breast cancer. DNAJC25 transcript levels are upregulated in BT-20 and ZR-75-1 cell lines and downregulated in MDA-MB-231 cell line compared to the non-tumorigenic mammary epithelial cell line (MCF 10A) ( $P<0.05)$. According to UALCAN in-silico tool, clinical breast cancer samples show significantly reduced levels of DNAJC25 mRNA relative to the normal samples $(P=1.47 \mathrm{e}-02)$. The Kaplan-Meier plotter tool shows that high DNAJC25 expression is favorable for post-progression survival in breast cancer $(P=0.0035)$. Point mutations or copy number variations of $D N A J C 25$ are uncommon in clinical breast cancer samples. Combined bisulfite restriction analysis (COBRA) results showed that DNAJC25 promoter is not methylated in breast cell lines. Promoter hypomethylation was also observed in normal and tumor clinical samples (Beta-value<0.25). In conclusion, DNAJC25 is suggested as a tumor suppressor candidate having limited biomarker potential in breast cancer. Functional studies are essential to reveal its role in breast carcinogenesis.

\section{Key Words}

DNAJC25, HSP40, biomarker, breast cancer.

\section{Öz}

\begin{abstract}
NAJC25 geni HSP40 (DNAJ) ailesinin bir üyesidir ve hepatoselüler karsinomada tümör baskılayıcı gen olarak önerilmiştir. Bu çalışmanın amacı, meme kanserinde DNAJC25 geninin ifadesini, genetik/epigenetik değişimlerini ve prognostik önemini analiz etmekdir. DNAJC25 mRNA ifadesi meme kanseri hücre hatlarında farklılık göstermektedir. Tümörijenik olmayan meme epitel hücre hattına (MCF 10A) göre, DNAJC25 transkript seviyesi BT-20 ve ZR-75-1 hücre hatlarında upregüle olurken, MDA-MB-231 hücre hattında downregüle olmuştur $(P<0.05)$. UALCAN in-siliko aracına göre, klinik meme kanseri örnekleri normal örneklere göre anlamlı oranda düşük DNAJC25 mRNA seviyesi göstermektedir ( $P=1.47 e-02)$. Kaplan-Meier plot çizerine göre, DNAJC25 ifadesi meme kanserinde post-progres sağ kalımı için olumludur $(P=0.0035)$. DNAJC25 nokta mutasyonları veya kopya sayısı değişimleri klinik meme kanseri örneklerinde nadirdir. Kombine Bisülfit Restriksiyon Analiz (COBRA) sonuçları DNAJC25 promotorunun meme hücre hatlarında metile olmadığını göstermiştir. Promotor hipometilasyonu ayrıca normal ve tümör klinik örneklerinde de gözlenmiştir (Beta-value<0.25). Sonuç olarak, DNAJC25, meme kanserinde biyobelirteç potansiyeli düşük bir tümör baskılayıcı adayı olarak önerilmektedir. Meme kanseri karsinogenezindeki rolünü ortaya çıkarmak için fonksiyonel çalışmalar gereklidir.
\end{abstract}

\section{Anahtar Kelimeler}

DNAJC25, HSP40, biyobelirteç, meme kanseri.

Article History: Received: May 11, 2020; Revised: Dec 7, 2020; Accepted: Jan 7, 2021; Available Online: May 7, 2021.

DOI: https://doi.org/10.15671/hjbc.725263

Correspondence to: T. Acun, Department of Molecular Biology and Genetics, Zonguldak Bulent Ecevit University, Zonguldak, Turkey.

E-Mail: tolgaacun@yahoo.com 


\section{INTRODUCTION}

B reast cancer is a leading cause of cancer-related death among women worldwide [1]. New biomarkers or specific drug targets are needed for breast cancwer therapy. A number of Heat Shock Proteins (HSPs) and some DNAJ (HSP40) proteins are considered as biomarkers or selected as drug targets for cancer diagnosis/ prognosis and treatment [2, 3]. The aim of this study was to analyze the expression, genetic/epigenetic alterations, and prognostic value of the DNAJC25 gene in breast cancer.

DNAJ heat shock proteins constitute the biggest and most diverse sub-group of the HSP family. There are 49 DNAJ members which are divided into three subclasses: DNAJA, DNAJB and DNAJC. DNAJ proteins are regarded as "co-chaperones" as they regulate major chaperones; HSP70 and HSP90. Because of these regulatory actions DNAJ members are suggested as more specific and selective drug targets to be used in cancer therapy compared to major chaperones. Many DNAJ members are associated with carcinogenesis or they are regarded as biomarkers or drug targets $[2,3]$.

DNAJC25 gene is a member of the HSP40 (DNAJ) family, and it was suggested as tumor suppressor gene in hepatocellular carcinoma. DNAJC25 was shown to be downregulated in hepatocellular carcinoma (HCC) tissues relative to adjacent normal tissues. Besides, anti-carcinogenic properties of DNAJC25, such as colony growth inhibition and enhancement of apoptosis, were also shown [4]. According to the Protein Atlas, high DNAJC25 mRNA is favorable for endometrial cancer (http://www. proteinatlas.org) [5]. This study provides some pieces of evidence regarding the expression, genetic/epigenetic regulation, and the prognostic value of the DNAJC25 gene in breast cancer.

\section{MATERIALS and METHODS}

\section{Cell lines}

Breast cancer cell lines (BT-20, SK-BR-3, MDA-MB-231, ZR-75-1) and non-tumorigenic mammary epithelial cell line (MCF 10A) were kindly provided by Dr. I. Yulug (Bilkent University, Ankara, Turkey) and they cultured according to American Type Culture Collection guidelines (ATCC, Mannassas, VA, USA).

\section{Real-Time qRT-PCR}

RNeasy Mini Kit (Cat. No: 74104) (Qiagen, Germany) is used to isolate the total RNAs from the cell lines. RNAs are then used to synthesize cDNA by using Verso cDNA Synthesis Kit (Cat. No: AB1453A; Thermo Fisher Scientific Inc. MA, USA). Comparative CT method (2-ddCT method) [6] was used to measure the relative levels of DNAJC25 mRNA levels by using iTaq $^{\mathrm{TM}}$ Universal SYBR $^{\circledR}$ Green Supermix (Cat. No: 1725120). CFX96 Touch $^{\text {TM }}$ Real-Time PCR Detection System was used according to the manufacturer's instructions (Bio-Rad Laboratories, Inc., CA, USA). (DNAJC25 Forward: 5'-AAC GAG AGC TCT GGA TCA AGG-3', Reverse: 5'-AGG CCC TTC ATT CTT CAT CCA-3'). TBP (TATA box binding protein) gene was used as a reference [7] (TBP Forward 5'-TGC ACA GGA GCC AAG AGT GAA-3', Reverse 5'- CAC ATC ACA GCT CCC CAC CA-3). Statistical analyses were performed by Student's t-test. The $P$ value $<0.05$ was considered significant.

\section{In Silico Tools}

The relative DNAJC25 mRNA values and promoter methylation levels of clinical breast cancer samples (TCGA dataset) was analyzed by the UALCAN in-silico tool (http://ualcan.path.uab.edu/index.html) [8]. The Kaplan-Meier plotter (KM plotter) (www.kmplot.com) was used to evaluate the survival values of DNAJC25 mRNA levels in patients with breast cancer (The probeset Affy ID: 226859_at). The samples were divided according to DNAJC25 expression as high and low by selecting "Auto select best cutoff" option of the software [9]. The software calculated the Log rank $P$ value and the hazard ratio (HR) with 95\% confidence intervals and displayed them on the graph. The $P$ value $<0.05$ was considered significant.

\section{Genetic alterations of DNAJC25}

Point mutations and copy number variations of DNAJC25 gene were screened by using Sanger COSMIC (Catalogue of Somatic Mutations in Cancer) database (v91) [10]. 


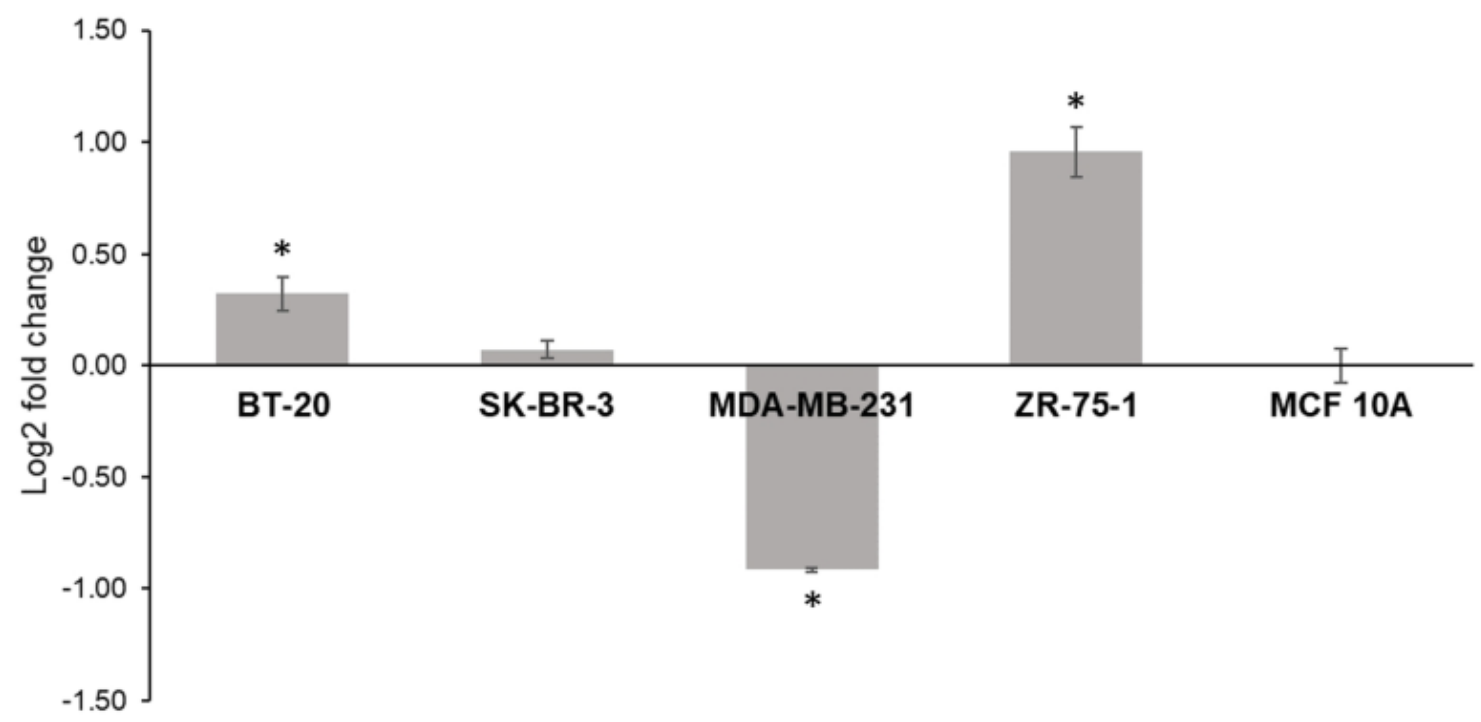

Figure 1. DNAJC25 expression in breast cancer cell lines relative to MCF 10A $\left({ }^{*} P<0.05\right)$.

\section{Combined bisulfite restriction analysis (COBRA)}

Genomic DNAs were isolated by DNeasy tissue kit (Qiagen, Germany) and treated with bisulfite by using EpiJET Bisulfite Conversion Kit (Cat. No: K146) (Thermo Scientific, MA, USA). The region of $\mathrm{CpG}$ island overlapping the DNAJC25 promoter was amplified by a Taq DNA polymerase (Cat. No: LSG-EP0402) (Thermo Scientific, MA, USA). (Forward 5'-GGG GAA GGT GTT TAG TGA TAT AT-3', Reverse 5'-AAT AAA ACC CCT CCA CCA AAA C-3'). PCR amplicons were digested with thal restriction en zyme (Cat. No: ER1851) (Thermo Scientific, MA, USA) as previously described [11]. M.Sssl enzyme (Cat. No: EM0821) (Thermo Scientific, MA, USA) was used to invitro methylate the genomic DNA of MCF $10 \mathrm{~A}$ cell line and used as a positive control.

\section{RESULTS}

\section{Differential expression of DNAJC25 in breast cancer cell lines}

DNAJC25 mRNA level is significantly reduced in MDAMB-231 (claudin-low, triple negative) breast cancer cell line compared to the non-tumorigenic mammary epithelial cell line (MCF 10A). BT-20 (basal, triple negative) and ZR-75-1 (luminal, ER+) cell lines have significantly high levels of DNAJC25 mRNA ( $P<0.05)$ (Figure 1) [12]. No significant difference was observed between SKBR-3 (HER2+) and MCF 10A cell lines regarding their DNAJC25 transcript levels.

\section{DNAJC25 mRNA expression is reduced in clinical breast cancer samples}

According to the UALCAN in-silico tool [8], DNAJC25 mRNA expression is reduced in clinical breast cancer samples (TCGA, $n=1097)$ compare to the normal samples $(n=114)$ $(P=1.47 e-02)$ (Figure 2a). HER2+ $(n=37)$ and Triple-Negative Breast Cancer (TNBC) $(n=116)$ clinical tumor samples have significantly low levels of DNAJC25 mRNA compared to normal samples $(\mathrm{n}=114)(\mathrm{P}=7.04 \mathrm{e}-08$ and $P=5.044 \mathrm{e}$ 12 respectively). Luminal samples $(n=566)$ have reduced levels of DNAJC25 transcripts ( $P=7.19 \mathrm{e}-01)$ (Figure $2 \mathrm{~b}$ ).

\section{DNAJC25 expression is favorable for post-progression survival in breast cancer}

The Kaplan-Meier plotter tool (http://kmplot.com) [9] shows that high DNAJC25 expression is favorable for postprogression survival in breast cancer $(n=173, P=0.0035)$ (Figure 3). But DNAJC25 expression has no significant survival value for the overall survival (OS), relapse-free survival (RFS), and distant metastasis-free survival (DMFS) (Supplementary Information). Breast cancer subtypes (basal, luminal A, luminal B, HER2+) were also analyzed for survival outcomes based on their DNAJC25 mRNA expression levels (Table 1, Supplementary Information). High DNAJC25 mRNA expression is favorable for luminal A subtype in DMFS and PPS. DNAJC25 mRNA expression is also favorable for HER2+ subtype in DMFS. But high DNAJC25 mRNA expression is unfavorable for luminal $B$ subtype in RFS and DMFS. It is also unfavorable for basal subtype in DMFS (Table 1, Supplementary Information). 
a

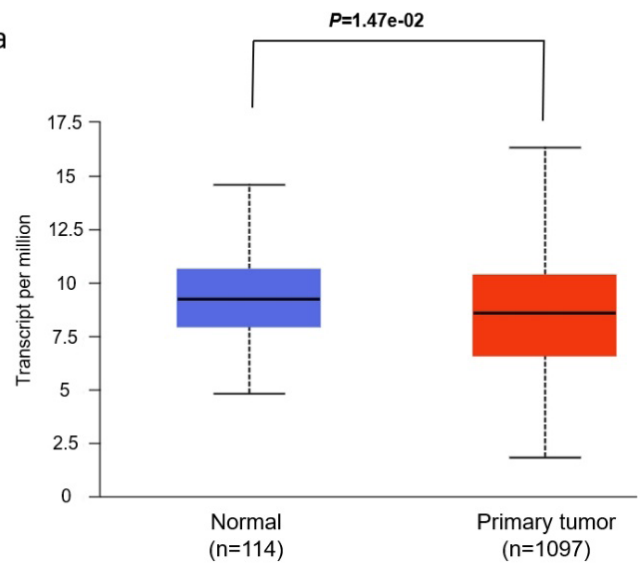

b

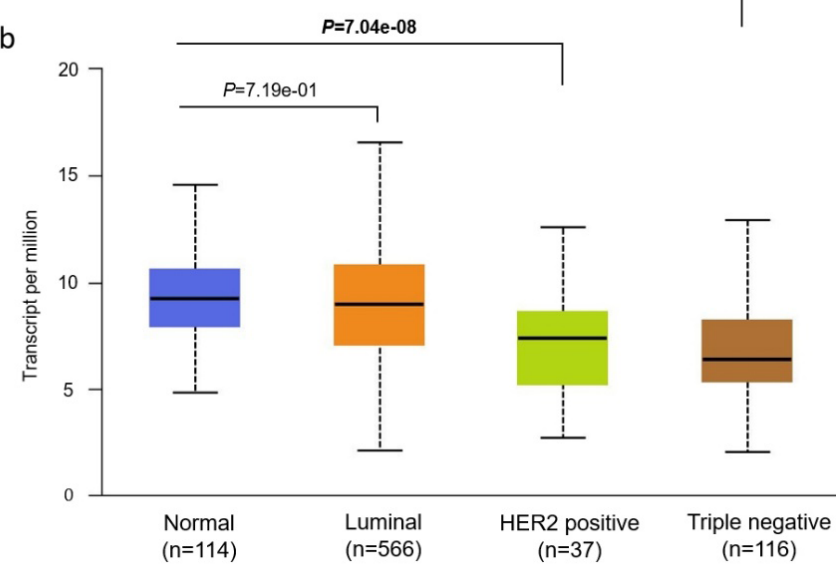

Figure 2. Relative DNAJC25 transcript levels in clinical tumor samples. Transcript levels of primary tumors (a), and samples of breast cancer subtypes (b) relative to normal samples are shown. Modified screen-view from UALCAN web resource was used. Significant P values are shown as bold.

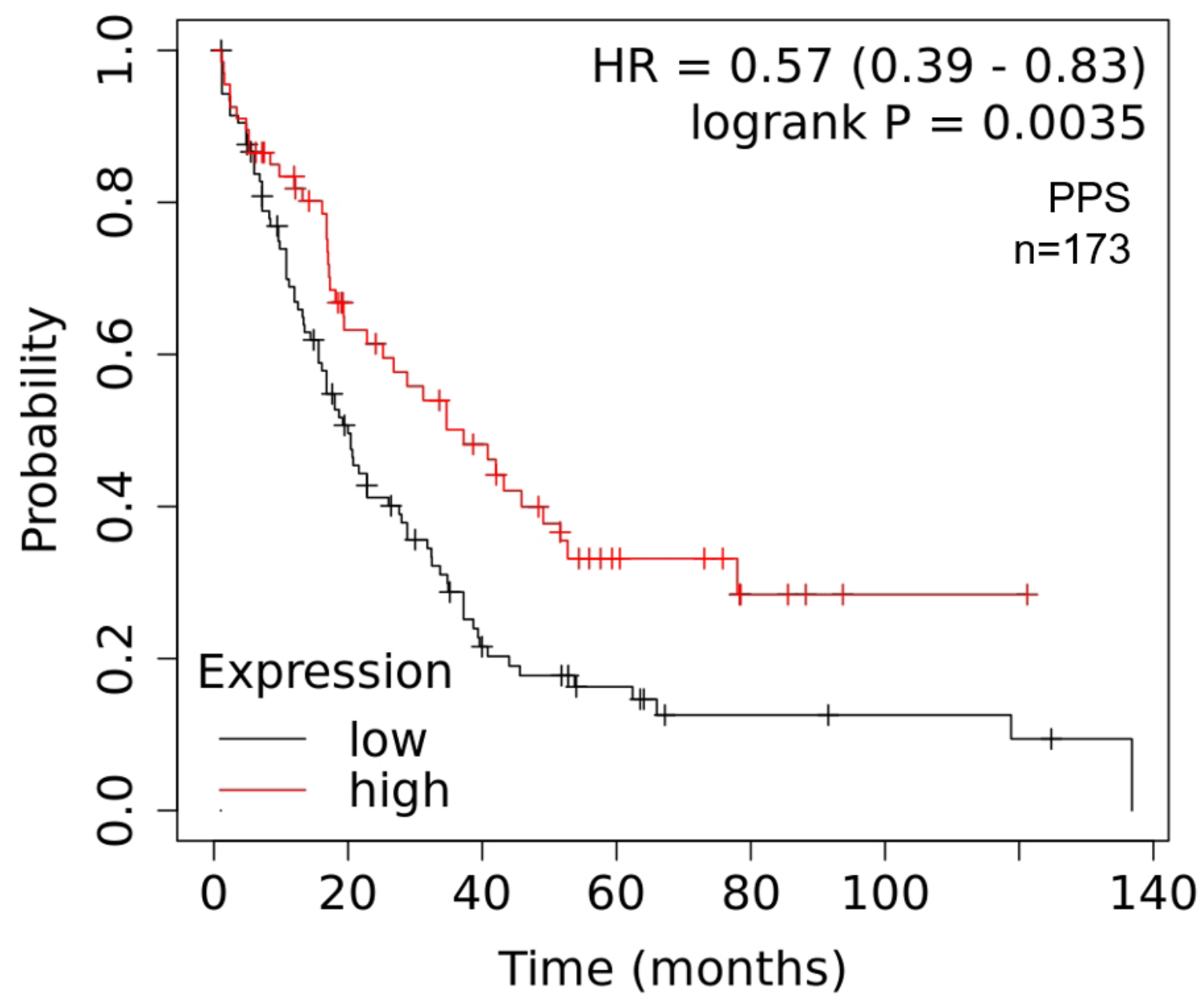

Figure 3. DNAJC25 expression is favorable for post-progression survival (PPS) in breast cancer ( $n=173, P=0.0035)$. Kaplan-Meier plot was generated by KM plotter (The probeset Affy ID: 226859_at). 
Table 1. Survival outcomes of DNAJC25 mRNA expression in breast cancer subtypes analyzed by KM-plotter tool.

\begin{tabular}{|c|c|c|c|c|}
\hline $\begin{array}{l}\text { Breast Cancer } \\
\text { Subtypes }\end{array}$ & $\begin{array}{l}\text { Overall } \\
\text { Survival }\end{array}$ & $\begin{array}{l}\text { Relapse-Free } \\
\text { Survival }\end{array}$ & $\begin{array}{l}\text { Distant Metastasis } \\
\text { Free Survival }\end{array}$ & $\begin{array}{l}\text { Post Progression } \\
\text { Free Survival }\end{array}$ \\
\hline Basal & $\begin{array}{c}\text { N.S. } \\
P=0.14, H R=1.66 \\
n=153\end{array}$ & $\begin{array}{c}\text { N.S. } \\
P=0.077, \mathrm{HR}=1.34 \mathrm{n}= \\
360\end{array}$ & $\begin{array}{c}\text { Unfavorable } \\
\mathrm{P}=0.047, \mathrm{HR}=2.08 \\
\mathrm{n}=145\end{array}$ & $\begin{array}{c}\text { N.S. } \\
P=0.078, H R=0.46 \\
n=33\end{array}$ \\
\hline Luminal A & $\begin{array}{c}\text { N.S. } \\
P=0.16 H R=0.68 n=271\end{array}$ & $\begin{array}{c}\text { N.S. } \\
P=0.076, H R=1.28 n= \\
841\end{array}$ & $\begin{array}{c}\text { Favorable } \\
\mathrm{P}=0.011, \mathrm{HR}=0.44 \mathrm{n}= \\
281\end{array}$ & $\begin{array}{c}\text { Favorable } \\
\mathrm{P}=0.045, \mathrm{HR}=0.55 \\
\mathrm{n}=75\end{array}$ \\
\hline Luminal B & $\begin{array}{c}\text { N.S. } \\
\mathrm{P}=0.13, \mathrm{HR}=1.68 \mathrm{n}= \\
129\end{array}$ & $\begin{array}{c}\text { Unfavorable } \\
\mathrm{P}=0.0058, \mathrm{HR}=1.54 \\
\mathrm{n}=407\end{array}$ & $\begin{array}{c}\text { Unfavorable } \\
\mathrm{P}=0.0065, \mathrm{HR}=2.41 \\
\mathrm{n}=156\end{array}$ & $\begin{array}{c}\text { N.S. } \\
\mathrm{P}=0.17, \mathrm{HR}=0.56 \\
\mathrm{n}=37\end{array}$ \\
\hline HER2+ & $\begin{array}{c}\text { N.S. } \\
P=0.31, H R=0.66 n=73\end{array}$ & $\begin{array}{c}\text { N.S. } \\
\mathrm{P}=0.13, \mathrm{HR}=1.47 \\
\mathrm{n}=156\end{array}$ & $\begin{array}{c}\text { Favorable } \\
\mathrm{P}=0.023, \mathrm{HR}=0.27 \\
\mathrm{n}=82\end{array}$ & $\begin{array}{c}\text { N.S. } \\
P=0.2, H R=1.76 \\
n=28\end{array}$ \\
\hline
\end{tabular}

(N.S.: Not Significant)

\section{Genetic alterations of DNAJC25 gene are uncommon in breast cancer}

Frequency of point mutations and copy number variations (CNV) of DNAJC25 is very low in breast cancer (Sanger COSMIC database, v92) [10] (Table 2).

\section{DNAJC25 promoter region is hypomethylated in breast cell lines and clinical samples.}

DNAJC25 gene has two experimentally validated promoter region, designated as DNAJC25_1 and DNAJC25_2 [13] DNAJC25_1, is very active promoter region compared to the DNAJC25_2 and it is located within the CpG island $[13,14]$
(Figure 4a). So, primers are designed to amplify the $\mathrm{CpG}$ island containing the DNAJC25_1 promoter region. COBRA results showed that breast cell lines are not methylated. (Figure 4b). According to UALCAN web resource, clinical breast cancer samples $(n=793)$ and normal samples $(n=97)$ are also hypomethylated (beta values $<0.25$ ) (Figure $4 c$ ) [8]. Besides, no significant difference was observed between normal and tumor samples ( $P=1.01 \mathrm{e}-01)$. Samples of breast cancer subtypes are also hypomethylated (data not shown).

Table 2. Genetic alterations of DNAJC25 in breast cancer. 
a

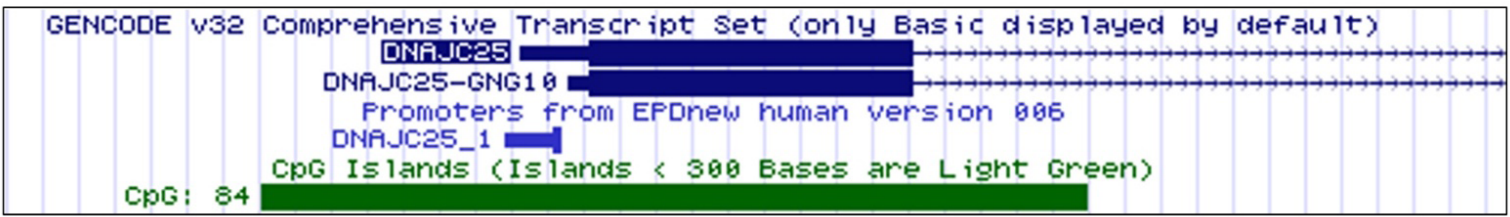

b

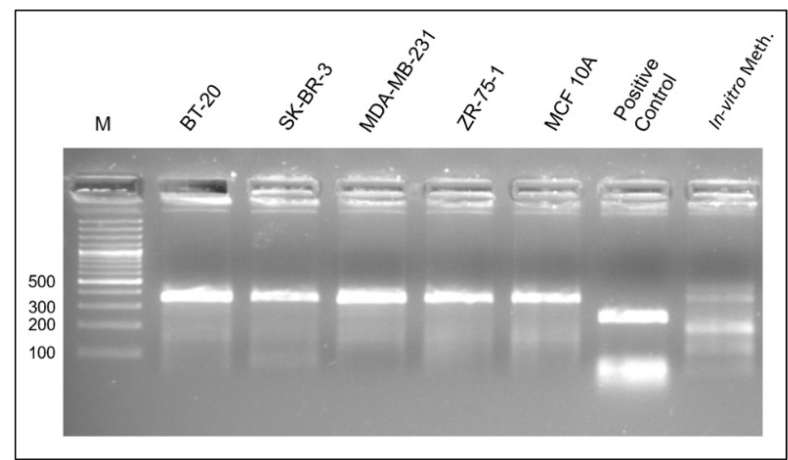

C

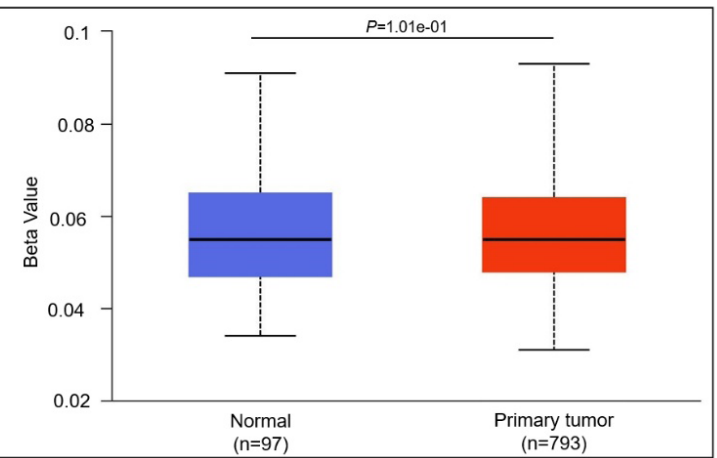

Figure 4. DNAJC25 promoter region is hypomethylated in breast cell lines and clinical samples. a. Promoter region of DNAJC25 gene (DNAJC25_1) overlapping the CpG island (screen-view of UCSC genome browser, http://genome.ucsc.edu) b. COBRA results of breast cell lines with the expected digestion fragments of 188 bp, 112 bp, 53 bp from a 353 bp PCR amplicon. M: DNA ladder; Positive Control: an amplicon of $597 \mathrm{bp}$ having cutting site of Hhal restriction enzyme with the expected digestion fragments of $239 \mathrm{bp}$ and small fragments (70bp<); In-vitro Meth: In-vitro methylated genomic DNA. c. Modified screen view from UALCAN in-silico tool showing hypomethylation of DNAJC25 promoter in clinical breast samples (beta values $<0.25$ ).

\section{DISCUSSION}

Several lines of evidence showed that DNAJC25 gene act as a tumor suppressor gene in hepatocellular carcinoma [4]. Besides, high DNAJC25 mRNA is favorable for endometrial cancer (http://www.proteinatlas.org) [5]. The aim of this study is to analyze the expression, genetic/epigenetic regulation, and the prognostic value of the DNAJC25 gene in breast cancer.

Breast cell lines have differential DNAJC25 mRNA expression; upregulated in BT-20 (triple negative) and ZR-75-1 (luminal, ER+) cell lines, downregulated in MDA-MB-231 cell line (TNBC) relative to the MCF $10 \mathrm{~A}$ $(P<0.05)$ (Figure 1) [12]. BT-20 and MDA-MB-231 cell lines are both triple negative (ER-, PR-, HER2-) cell lines, but the expression levels of DNAJC25 are significantly different (Figure 1). It is important to emphasize that MDA-MB-231 cell line is also regarded as "claudin-low" phenotype as the genes involved in tight junctions and cell-cell adhesion such as claudin-3, claudin-4, claudin-7, and E-cadherin are down-regulated $[12,15]$. Moreover, different mutational signatures of those cell lines may also affect the expression level of DNAJC25 [16].
DNAJC25 mRNA levels are reduced in clinical breast cancer samples compared to the normal samples $(P=1.47$ e-02) (Figure 2). Regarding the prognostic survival values, DNAJC25 expression is favorable for postprogression survival, but not OS, RFS, and DMFS (Figure 3, Supplementary Information). As we observed differential DNAJC25 mRNA expression in breast cell lines representative of different subtypes (Figure 1), clinical samples from the breast cancer subtypes (basal, luminal $A$, luminal $B, H E R 2+$ ) were also analyzed for their DNAJC25 expression (Figure 2b) and survival outcomes based on their DNAJC25 expression levels (Table 1, Supplementary Information) by using UALCAN and KMplotter tools, respectively. DNAJC25 mRNA expression is reduced in clinical samples representing the breast cancer subtypes compare to the normal samples (Figure $2 b$ ). But survival outcomes have some subtype specific differences (Table 1, Supplementary Information). It should be noted that the cohorts used for the expression and survival analyses are not the same. UALCAN tool uses the TCGA datasets, but the KM-plotter uses the data gathered from Gene Expression Omnibus (GEO) and ArrayExpress. 
Since, genetic alterations are infrequent, DNA methylation was sought as a possible regulation mechanism for DNAJC25. DNAJC25 promoter is not methylated in breast cell lines (Figure 4b) and clinical breast cancer samples (Figure 4c). High levels of DNAJC25 mRNA in BT-20 and ZR-75-1 cell lines could be explained by promoter hypomethylation. But this epigenetic event could not explain low levels of DNAJC25 mRNA in MDAMB-231 compare to MCF 10A. Some other epigenetic mechanisms, such as histone modifications or miRNAs, may be affecting the cellular DNAJC25 levels in MDAMB-231 cell line.

In conclusion, DNAJC25 is downregulated in breast cancer, and its expression is favorable for post-progression survival. Functional assays are needed to clarify the role and regulation of this gene in breast cancer.

Acknowledgments - The author thanks Dr. Isik Yulug and members of the Yulug Group (Bilkent University, Ankara, Turkey) for kindly providing the breast cell lines. This project was supported by grant from Zonguldak Bulent Ecevit University (Zonguldak, Turkey) (Grant No: 2017-50737594-02) to Dr. Tolga ACUN.

\section{References}

1. F. Bray, J. Ferlay, I. Soerjomataram, R.L. Siegel, L.A. Torre, and A. Jemal, Global cancer statistics 2018: GLOBOCAN estimates of incidence and mortality worldwide for 36 cancers in 185 countries, CA. Cancer J. Clin., 68 (2018) 394424.

2. A.A. Khalil, N.F. Kabapy, S. F. Deraz, and C. Smith, Heat shock proteins in oncology: Diagnostic biomarkers or therapeutic targets?, Biochim. Biophys. Acta - Rev. Cancer, 1816 (2011) 89-104.

3. J.N. Sterrenberg, G.L. Blatch, and A.L. Edkins, Human DNAJ in cancer and stem cells, Cancer Lett., 312 (2011) 129-142.

4. T. Liu, W. Jiang, D. Han, L. Yu, DNAJC25 is downregulated in hepatocellular carcinoma and is a novel tumor suppressor gene, Oncol. Lett., 4 (2012) 1274-1280.

5. M. Uhlen, L. Fagerberg, B.M. Hallstrom et al., Tissue-based map of the human proteome, Science, 347 (2015) 1260419.

6. K.J. Livak and T.D. Schmittgen, Analysis of relative gene expression data using real-time quantitative PCR and the 2(-Delta Delta C(T)) Method, Methods, 25 (2001) 402-408.

7. B. Gur-Dedeoglu, O. Konu, B. Bozkurt, G. Ergul, S. Seckin, and I.G. Yulug, Identification of endogenous reference genes for qRT-PCR analysis in normal matched breast tumor tissues, Oncol. Res., 17 (2009) 353-365.

8. D.S. Chandrashekar et al., UALCAN: A Portal for Facilitating Tumor Subgroup Gene Expression and Survival Analyses, Neoplasia, 19 (2017) 649-658.

9. B. Györffy et al., An online survival analysis tool to rapidly assess the effect of 22,277 genes on breast cancer prognosis using microarray data of 1,809 patients, Breast Cancer Res. Treat., 123 (2010) 725-731.

10. S.A. Forbes et al., COSMIC: somatic cancer genetics at highresolution, Nucleic Acids Res., 45 (2017) 777-783.

11. Z. Xiong and P. W. Laird, COBRA: a sensitive and quantitative DNA methylation assay, Nucleic Acids Res., 25 (1997) 25322534.

12. L.M. Heiser, A. Sadanandam, W.L. Kuo et al., Subtype and pathway specific responses to anticancer compounds in breast cancer, Pro Natl Aca Sc USA, 109 (2012) 2724-2729.

13. R. Dreos, G. Ambrosini, R.C. Périer, and P. Bucher, The Eukaryotic Promoter Database: expansion of EPDnew and new promoter analysis tools, Nucleic Acids Res., 43 (2015) 92-96.

14. W.J. Kent et al., The Human Genome Browser at UCSC, Genome Res., 12 (2002) 996-1006.

15. D.L. Holliday, V. Speirs, Choosing the right cell line for breast cancer research, Breast Cancer Res., 13 (2011) 215.

16. K.J. Chavez, S.V. Garimella, S. Lipkowitz, Triple negative breast cancer cell lines: one tool in the search for better treatment of triple negative breast cancer, Breast Dis., 32 (2010) 35-48. 
Supplemental Figure 1. Survival statistics of DNAJC25 mRNA expression for the overall survival (OS), relapse-free survival (RFS), distant metastasis-free survival (DMFS) and post-progression survival (PPS) in breast cancer. Kaplan-Meier plots were generated by KM-plotter (The probeset Affy ID: 226859_at).
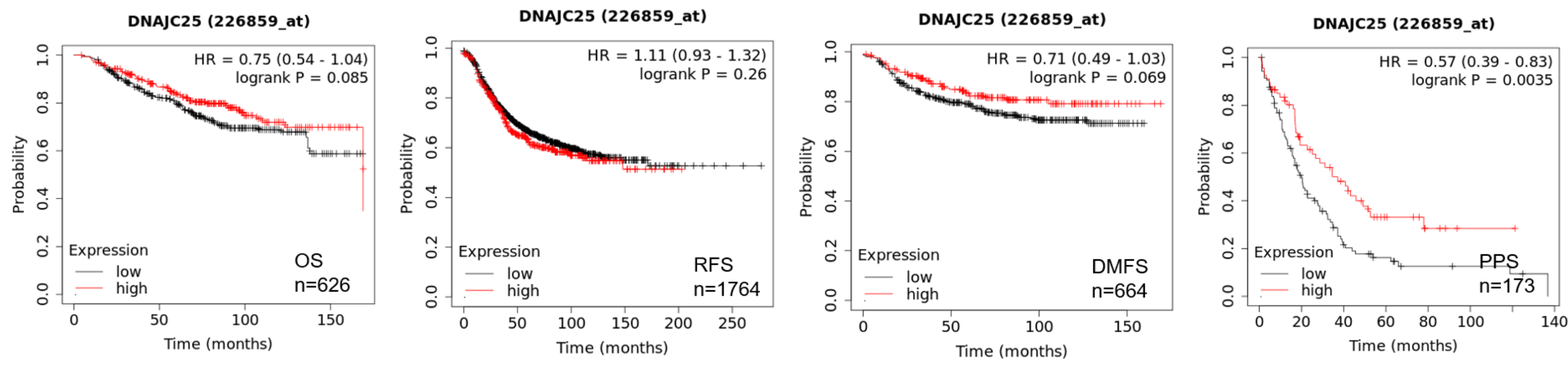
Supplemental Figure 2. Survival statistics of DNAJC25 mRNA expression in breast cancer subtypes. Kaplan-Meier plots were generated by KM-plotter (The probeset Affy ID: 226859_at).
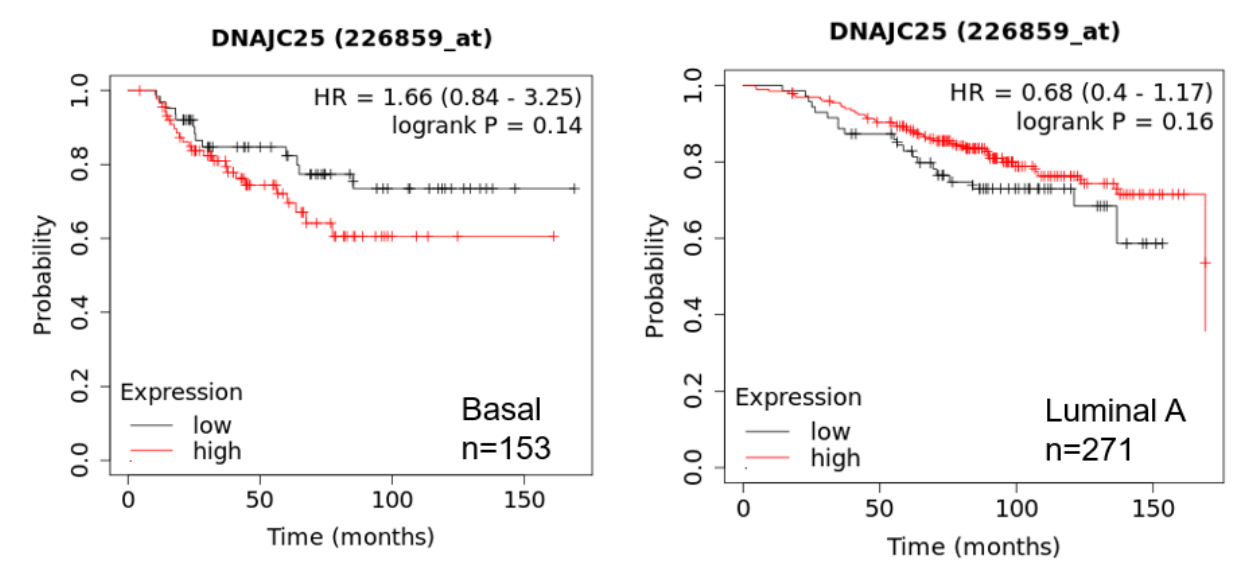

\section{Overall Survival}
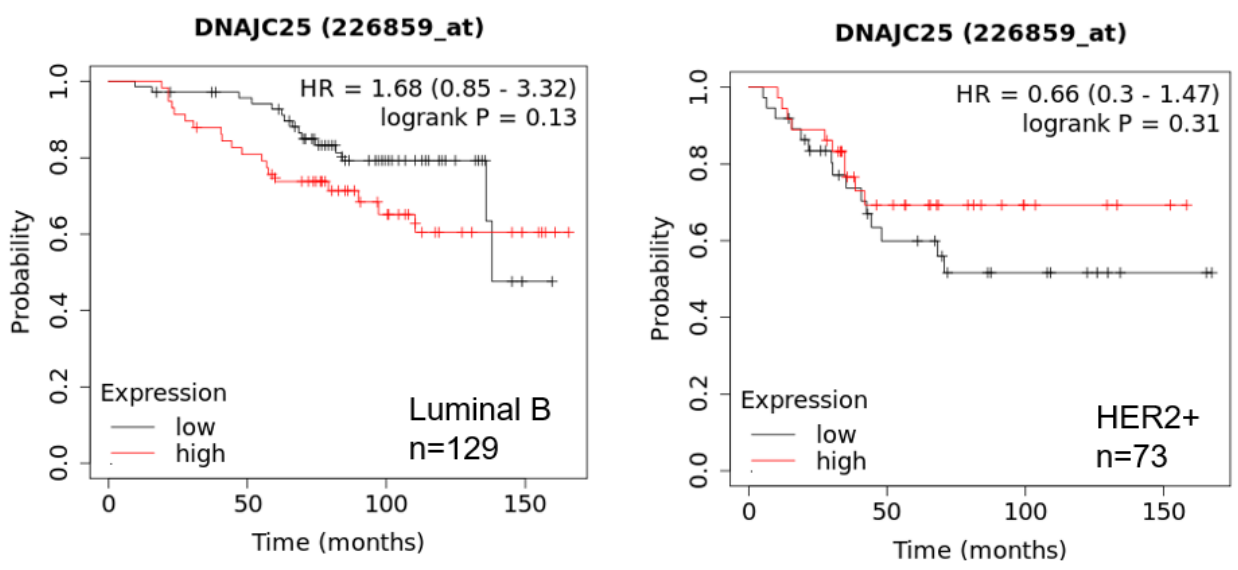

\section{Relapse Free Survival}
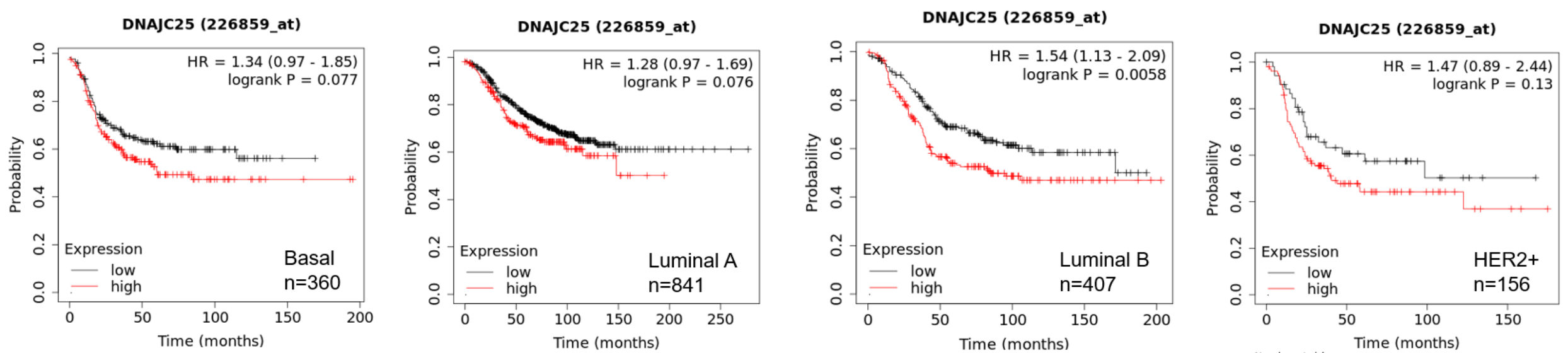
Distant Metastasis Free Survival
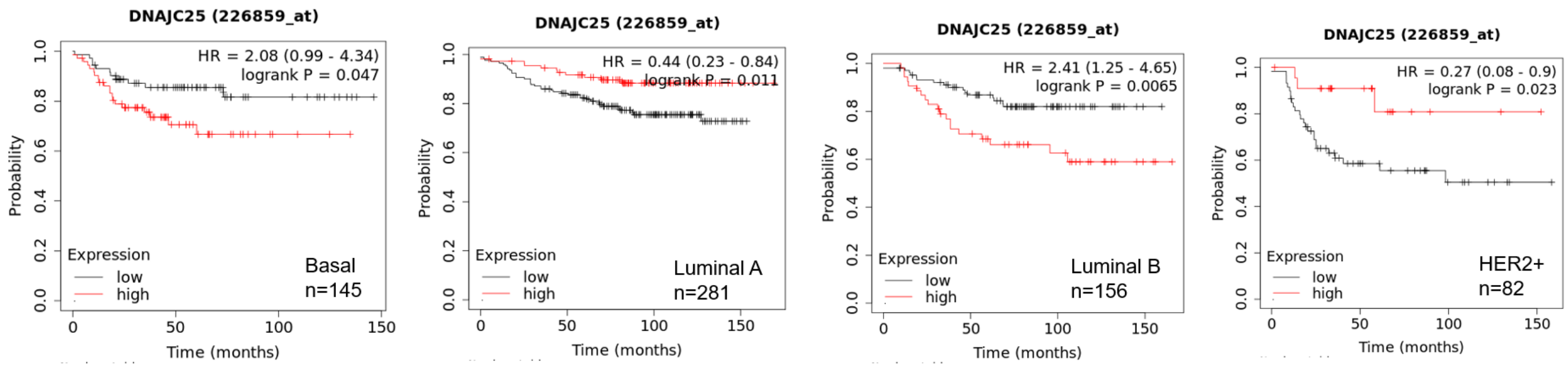

\section{Post Progression Free Survival}
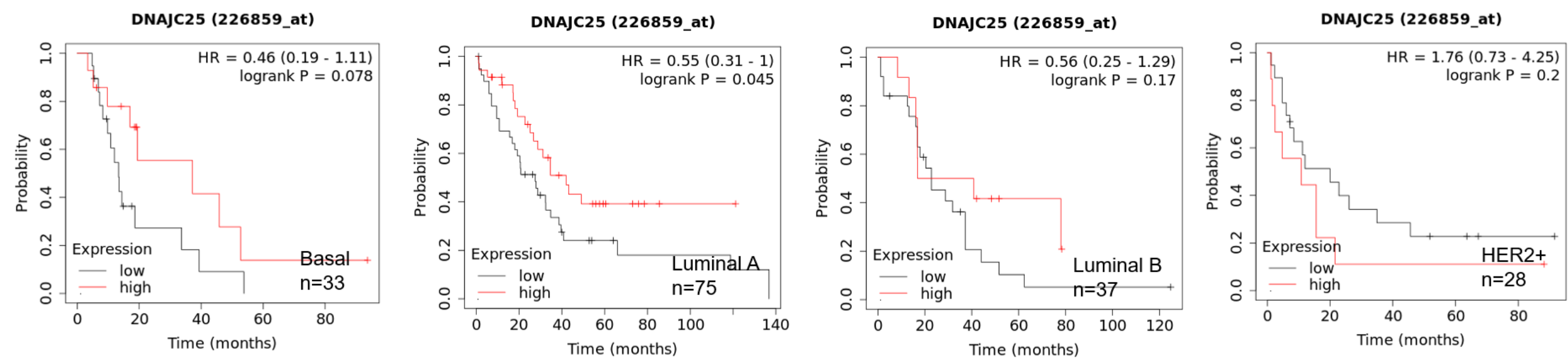